\title{
Plasminogen Activator Inhibitor-1 Deficiency
}

National Cancer Institute

\section{Source}

National Cancer Institute. Plasminogen Activator Inhibitor-1 Deficiency. NCI Thesaurus.

Code C133884.

An autosomal recessive condition caused by mutation(s) in the PAl1 gene, encoding plasminogen activator inhibitor 1. It is characterized by increased bleeding following trauma, injury, or surgery and in women, menorrhagia. 